\title{
Erratum to: Nonclassically Secreted Proteins as Possible Antigens for Vaccine Development: A Reverse Vaccinology Approach
}

Mauricio de Alvarenga Mudadu ${ }^{1} \cdot$ Viviane Carvalho $^{2} \cdot{\text { Sophie Yvette } \text { Leclercq }^{2}}^{2}$

Published online: 19 October 2015

(C) Springer Science+Business Media New York 2015

\section{Erratum to: Appl Biochem Biotechnol (2015) 175:3360-3370 \\ DOI 10.1007/s12010-015-1507-4}

The acknowledgment section is missing in the original version of this article. The details are given below:

Acknowledgments This study was supported by the grant from the Fundação de Amparo à Pesquisa do Estado de Minas Gerais (Fapemig)- APQ-00442-12.

The online version of the original article can be found at http://dx.doi.org/10.1007/s12010-015-1507-4.

Sophie Yvette Leclercq

sophie.leclercq@funed.mg.gov.br

1 Embrapa Southeast Livestock, São Carlos, São Paulo, Brazil

2 Research and Development Center, Ezequiel Dias Foundation (Funed), Belo Horizonte, MG, Brazil 